\title{
Job refusal sparks row over mind-drug critic
}

\section{David Spurgeon, Montreal}

Canada's leading research university is coming under fire after one of its affiliated hospitals withdrew a job offer to a prominent critic of psychological drugs.

Late last year, the Centre for Addiction and Mental Health (CAMH) at the University of Toronto hastily retracted an offer to David Healy, a reader in psychological medicine at the University of Wales College of Medicine in Cardiff, to become clinical director of its mood and anxiety disorders programme.

In a letter to Robert Birgeneau, president of the University of Toronto, the contents of which were made public earlier this month, 27 eminent scientists said that the handling of the affair was "besmirching the name of one of North America's great research universities", and was an "affront to the standards of free speech and academic freedom".

David Naylor, the university's dean of medicine, hit back on 7 September, calling the letter "misdirected" and saying that the authors - including two Nobel prizewinners and six past presidents of professional societies - should have discussed its contents with the university before releasing it publicly.

The post offered to Healy, which included a 'status-only' professorship, was rescinded after he gave a lecture at the university in which he was said to have criticized the use of so-called 'psychotropic' drugs. These include the antidepressant Prozac, made by Eli Lilly and Co., which contributes funds to the CAMH. Media reports in Canada suggested that this link with industry influenced the decision to withdraw the employment offer.

Naylor denies any such influence. "This is an issue where a partner (CAMH) has made a decision on a clinical leadership position and then, unfortunately, decided to reverse the decision," he says. He adds that the university will still provide an academic appointment

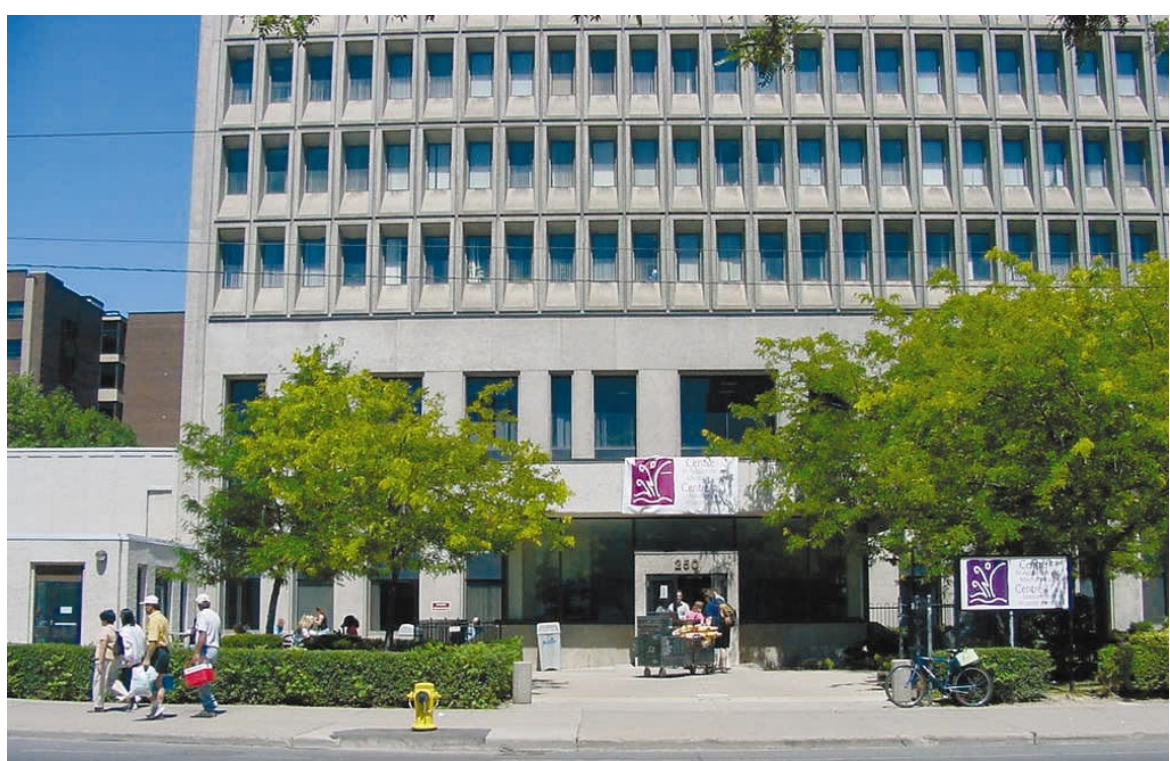

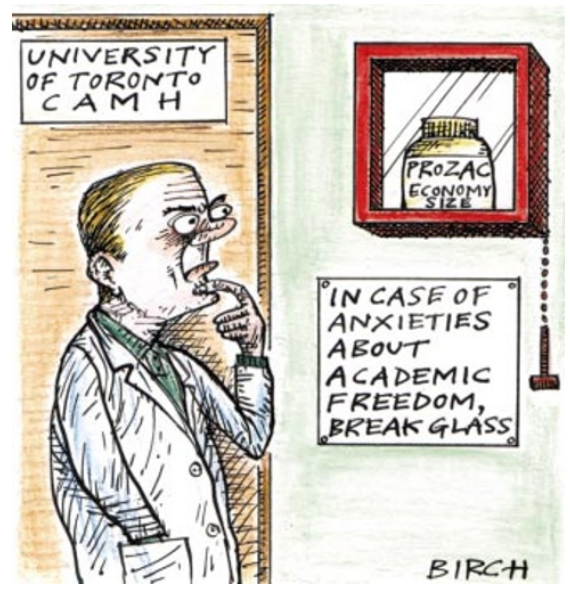

for Healy, provided that he gets a medical appointment in an affiliated hospital.

Naylor says the recruitment process has been "less than ideal", but argues that criticism of the university "reflects a fundamental

\section{Mad cow disease comes to Japan}

Jim Giles

The reach of mad cow disease extended around the globe on 10 September, when Japan announced the first confirmed case of bovine spongiform encephalopathy (BSE) in a cow born outside Europe.

Japanese officials say that a cow in the Chiba prefecture, east of Tokyo, has been diagnosed with the disease. All previous cases outside Europe involved cattle imported from Britain.

Researchers think that BSE originally entered Japan through infected meat and bonemeal cattle feed imported from Britain during the early 1990s. But worryingly for Japan's farmers, the disease may now have spread to domestic cattle feed.

Unconfirmed reports say that the animal that died was 5 years old. Experts say that British cattle feed was probably BSE-free by the time the cow was born, suggesting that the infection came from foodstuffs produced in Japan itself, perhaps using animal parts from cattle that had carried earlier, undetected infection from British feed.

"There could have been a new round of infection," says Marcus Doherr, a BSE expert at the University of Bern in Switzerland. But Doherr says that Japan is unlikely to see an epidemic on the British scale, as cattle feed made from animal parts was not as widely used in Japan as in Britain.
Focus of controversy: the Centre for Addiction and Mental Health in Toronto.

misunderstanding" of its relationship with clinical affiliates, such as the CAMH. The offer to Healy involved no university resources and was not a tenure-track appointment, Naylor says.

Those who heard the lecture, on 30 November, differ about what Healy actually said. Paul Garfinkel, head of the CAMH, says that CAMH staff present told him they were "shocked and alarmed" at Healy's statements on the hazards of some antipsychotic drugs. Garfinkel says that Healy has lost the support and respect of colleagues.

"This has nothing to do with academic freedom," says Garfinkel. "No one disputes Healy's freedom to say whatever he wants, and in a university setting this is encouraged. But in a hospital we have to worry about quality of patient care first."

Healy says that he did not say anything new in his lecture, and that it was well received by the audience, including many clinicians. This is "in complete contrast to what has been said by Dr Naylor and Dr Garfinkel", he adds. Healy also says that few CAMH staff were present, and that the only objector was CAMH chief physician David Goldbloom, whom Healy says was not enthusiastic about what he said on the hazards of some antipsychotic drugs.

Thomas Ban, emeritus professor of psychiatry at Vanderbilt University in Nashville, Tennessee, who composed the letter to Birgeneau, says that academic freedom is the sole issue involved. Margaret Somerville, director of the Centre for Medicine, Law and Ethics at McGill University in Montreal, says: "When you put universities and industry together, you get these conflicts."

www.pharmapolitics.com 